\section{Assessment of the independent associations of IgG, IgM and IgA isotypes of anticardiolipin with thrombosis in SLE}

\author{
Vinicius Domingues, ${ }^{1}$ Laurence S Magder, ${ }^{2}$ Michelle Petri ${ }^{3}$
}

To cite: Domingues V, Magder LS, Petri M. Assessment of the independent associations of $\lg \mathrm{G}, \lg M$ and $\lg A$ isotypes of anticardiolipin with thrombosis in SLE. Lupus Science \& Medicine 2016;3: e000107. doi:10.1136/lupus2015-000107

Received 3 June 2015 Revised 21 April 2016 Accepted 30 April 2016

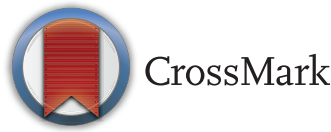

${ }^{1}$ Department of Rheumatology, New York University School of Medicine, New York New York, USA

${ }^{2}$ Department of Epidemiology and Public Health, University of Maryland, School of Medicine, Baltimore, Maryland, USA

${ }^{3}$ Division of Rheumatology, Johns Hopkins University School of Medicine, Baltimore, Maryland, USA

Correspondence to Dr Michelle Petri; mpetri@jhmi.edu

\section{ABSTRACT}

Objective: The Sydney classification criteria for antiphospholipid syndrome include lupus anticoagulant or moderate-to-high titre anticardiolipin IgG or IgM. We explored the association of all anticardiolipin isotypes, lupus anticoagulant and the combination with venous and arterial thrombosis.

Methods: Patients with systemic lupus erythematosus (SLE) in a large clinical cohort seen quarterly were repeatedly tested by protocol for anticardiolipin antibodies and lupus anticoagulant. Subgroups of patients were defined based on the geometric mean titres of $\lg G, \lg M, \lg A$ anticardiolipin and lupus anticoagulant expressed in dilute Russell's viper venom time (RVVT) seconds for each patient across all cohort visits. These subgroups were compared with respect rates of thrombosis since diagnosis with SLE. Rate ratios were estimated using Cox Proportional Hazards models.

Results: Of the 1390 cohort members included there were 284 thrombotic events observed over 17025 person-years since diagnosis for a rate of 1.7 events per 100 person-years. Those with a geometric mean titre of IgG anticardiolipin $>20$ had a significantly elevated rate of thromboses (rate ratio $1.8, p=0.0052$ ), whereas there was no evidence of an association between thromboses and elevated IgM geometric mean (rate ratio 1.2, $p=0.40$ ). There were relatively few cohort members with elevated IgA geometric mean but the rate of thromboses in that group was elevated (rate ratio 1.7, $p=0.23$ ). The associations between anticardiolipin antibodies and thromboses were strongest when considering venous thromboses. Those with two or more elevated anticardiolipin isotypes or those with both IgG anticardiolipin and RVVT did not appear at higher risk than those with a single elevated marker.

Conclusion: This study supports previous observations that IgG anticardiolipin and lupus anticoagulant are associated with higher rates of thromboses. Our power to study IgA anticardiolipin was limited due to small number of patients with elevated $\lg A$

\section{KEY MESSAGES}

Combining different isotypes of anticardiolipin does not increase risk.

- Additive scores for aPL antibodies do not seem useful in SLE.

- Lupus anticoagulant is still the best predictor of thrombosis.

\section{INTRODUCTION}

Antiphospholipid syndrome (APS) is characterised by clinical evidence of thrombophilia or pregnancy morbidity, together with laboratory evidence of either lupus anticoagulant by clotting methods and/or anticardiolipin and anti- $\beta 2$-glycoprotein 1 detected by ELISA. ${ }^{1}$ The Sydney APS classification criteria include the presence of lupus anticoagulant, moderate-to-high titre anticardiolipin and anti- $\beta 2$-glycoprotein 1 , but only isotypes IgG and IgM. ${ }^{1}$ Several studies have suggested that the combination of different antiphospholipid antibodies might be a better predictor of thrombosis risk ${ }^{2} 3$ and that IgA isotypes might have importance. ${ }^{2}$ The potential utility of summing or combining anticardiolipin isotypes is suggested by earlier studies that used polyclonal anticardiolipin assays, as opposed to isotype-specific ones. ${ }^{4-6}$

Since 2003, in our large clinical cohort study, patients with lupus were assessed for antiphospholipid antibodies by protocol every 3 months. This allowed us to look at the relationship between antiphospholipid antibodies and risk of thrombosis.

\section{METHODS}

The Hopkins Lupus Cohort, conceived in 1987, comprises patients with systemic lupus erythematosus (SLE) receiving ongoing care at Johns Hopkins University School of Medicine. This study is approved on an 
annual basis by the Johns Hopkins University School of Medicine Institutional Review Board. Informed written consent is obtained from all subjects. Subjects enrolled in the cohort have clinic visits at 3-month intervals or more frequently, if medically necessary.

\section{Measurement of APL antibodies}

Since 2003, anticardiolipin (ELISA IgG, IgM, IgA; Inova Diagnostics, San Diego, California, USA) was assessed at the large majority of clinic visits. The lupus anticoagulant was determined by dilute Russell's viper venom time (RVVT) and confirmatory mixing studies, if prolonged. We excluded RVVT measures made while patients were taking anticoagulants (eg, warfarin, heparin or, more recently, novel oral anticoagulants).

\section{Determining the occurrence of thromboses}

A patient's history of thrombotic events was determined at cohort entry by review of all historical records and patient interview and was updated at each visit. Deep venous thrombosis was defined by ultrasound or venogram and pulmonary embolus by ventilation/perfusion scan or spiral CT. Arterial thrombosis, in case of stroke, was defined by brain MRI or CT and, in case of myocardial infarction, by appropriate electrocardiographic changes, creatine kinase or troponin change or cardiac imaging. Other arterial thrombosis was defined as appropriate for the site involved.

\section{Statistical methods}

This analysis was based on 1390 cohort patients who had anticardiolipin isotypes (IgG, $\operatorname{IgM}$ and $\operatorname{IgA}$ ) measured at three or more cohort visits and who did not have a history of a thrombosis prior to diagnosis with SLE. For each patient, we calculated their geometric mean anticardiolipin titres and geometric mean RVVT. These geometric means were calculated by calculating the mean of the $\log ($ titre+1) and then exponentiating the mean. We chose the geometric mean rather than the arithmetic mean because the distribution of titres is highly skewed and the geometric mean is less affected by extreme values. Then we divided the patients into subgroups defined by their geometric means and compared the groups with respect to rates of thrombosis since SLE diagnosis. Rate ratios were estimated using Cox Proportional Hazards models.

\section{RESULTS}

There were 2393 patients who were ever in the Hopkins Lupus Cohort from 2007 to 2015. Of these, there were 1488 with three or more measures of anticardiolipin. Furthermore, 92 patients had a history of thrombosis before SLE diagnosis and were excluded as well as six others with thrombosis of unknown date. The final analysis includes the remaining 1390 patients.

The characteristics of these patients are shown in table 1. Most were Caucasian or African-American.
Table 1 Characteristics of the 1390 patients included in this study

\begin{tabular}{lc}
\hline Patient characteristic & No. (\%) \\
\hline Sex & \\
$\quad$ Female & $1286(93)$ \\
$\quad$ Male & $104(7)$ \\
Race & \\
$\quad$ Caucasian & $708(51)$ \\
African-American & $550(40)$ \\
Other & $132(10)$ \\
Age (years) at SLE diagnosis & \\
$<30$ & $689(50)$ \\
$30-44$ & $466(34)$ \\
$45-59$ & $191(14)$ \\
$60+$ & $44(3)$ \\
SLE duration (years) at cohort entry & \\
$<1$ & $565(41)$ \\
$1-3$ & $226(16)$ \\
$3-6$ & $193(14)$ \\
$6+$ & $406(29)$ \\
No. of years at risk since SLE diagnosis & \\
$1-5$ & $319(23)$ \\
$5-10$ & $319(23)$ \\
$10-15$ & $298(21)$ \\
$15+$ & $454(33)$ \\
\hline 0.06
\end{tabular}

No. of cohort visits during which anticardiolipin and RVVT

were measured

3-10

$10-19$

$401(29)$

$318(23)$

$20+$

SLE manifestations (based on ACR-11 criteria)

Malar rash

Discoid rash

Photosensitivity

$671(48)$

Oral ulcers

Arthritis

Serositis

780 (56)

$320(23)$

$797(57)$

$700(50)$

$1084(78)$

$733(53)$

Renal

Neurological

$665(48)$

$188(14)$

$994(72)$

Haematological

1155 (83)

ANA

1330(96)

ACR, American College of Rheumatology; ANA, anti nuclear antibody; RVVT, Russell's viper venom time; SLE, systemic lupus erythematosus.

Almost half were diagnosed before the age of 30 . Entry into the cohort occurred within a year of diagnosis for $41 \%$ of the patients. About $48 \%$ of the patients had an anticardiolipin measurement at more than 20 cohort visits.

These patients accrued a total of 17025 years at risk from the time of their diagnosis to the time of a thrombosis or end of follow-up (an average of 12.2 years/ patient). During this time, there were a total of 284 thromboses (rate of 1.7 per 100 person-years); 127 were prior to cohort entry and reported retrospectively and 157 were observed prospectively during cohort participation. Of the 284 thromboses, $46 \%$ were arterial, $51 \%$ were venous and $3 \%$ were reported as both. 
Table 2 shows the relationship between anticardiolipin antibody isotypes and lupus anticoagulant with any thrombosis (either venous or arterial). The rate of thromboses was significantly elevated among those with a geometric mean titre of the $\operatorname{IgG}$ isotype of $\geq 20$ (rate ratio $1.8, \mathrm{p}=0.0052$ ). The rate was similarly elevated among those with high levels of IgA; however, the number of patients in this subgroup was relatively low and this relationship did not reach statistical significance. We did not observe an association between elevated IgM anticardiolipin and thrombosis rate. An elevated geometric mean RVVT was associated with a higher rate of thrombosis (rate ratio 1.7, $\mathrm{p}=0.021$ ) .

Tables 3 and 4 show the relationship between levels of each anticardiolipin antibody and rates of arterial or venous thromboses, respectively. In general, there was a higher association between anticardiolipin antibodies and venous thromboses than arterial thromboses. One exception is that we observed a relatively high rate of arterial thromboses among those with elevated IgA anticardiolipin. However, this finding was based on only four thromboses.

Table 2 Relationship between any thrombotic event and mean levels of anticardiolipin isotypes

\begin{tabular}{|c|c|c|c|c|c|c|}
\hline $\begin{array}{l}\text { aCL } \\
\text { measure }\end{array}$ & $\begin{array}{l}\text { Subgroup defined by geometric } \\
\text { mean titre over all measures } \\
\text { during cohort }\end{array}$ & $\begin{array}{l}\text { No. of } \\
\text { thromboses }\end{array}$ & $\begin{array}{l}\text { No. of } \\
\text { person-years }\end{array}$ & $\begin{array}{l}\text { Rate } \\
\text { (per } \\
\text { 1000) }\end{array}$ & Rate ratios & p Value \\
\hline \multirow[t]{2}{*}{$\lg G$} & $<20(n=1318)$ & 259 & 16175 & 16.1 & 1.0 (Ref. group) & \\
\hline & $20+(n=72)$ & 25 & 850 & 29.4 & $1.8(1.2,2.7)$ & 0.0052 \\
\hline \multirow[t]{2}{*}{$\operatorname{lgM}$} & $<20(n=1320)$ & 267 & 16219 & 16.5 & 1.0 (Ref. group) & \\
\hline & $20+(n=70)$ & 17 & 809 & 21.0 & $1.2(0.8,2.0)$ & 0.40 \\
\hline \multirow[t]{2}{*}{$\lg A$} & $<20(n=1379)$ & 279 & 16848 & 16.7 & 1.0 (Ref. group) & \\
\hline & $20+(n=11)$ & 5 & 177 & 28.2 & $1.7(0.7,4.2)$ & 0.23 \\
\hline \multirow[t]{2}{*}{ RVVT } & $<45(n=1208)$ & 191 & 15243 & 12.5 & 1.0 (Ref. group) & \\
\hline & $45+(n=78)$ & 22 & 1015 & 21.7 & $1.7(1.1,2.6)$ & 0.021 \\
\hline
\end{tabular}

Table 3 Relationship between arterial thrombotic events and mean levels of anticardiolipin isotypes

\begin{tabular}{|c|c|c|c|c|c|c|}
\hline $\begin{array}{l}\text { aCL } \\
\text { measure }\end{array}$ & $\begin{array}{l}\text { Subgroup defined by geometric } \\
\text { mean titre over all measures } \\
\text { during cohort }\end{array}$ & $\begin{array}{l}\text { No. of } \\
\text { thromboses }\end{array}$ & $\begin{array}{l}\text { No. of } \\
\text { person-years }\end{array}$ & $\begin{array}{l}\text { Rate } \\
\text { (per } \\
\text { 1000) }\end{array}$ & Rate ratios & $\begin{array}{l}p \\
\text { Value }\end{array}$ \\
\hline \multirow[t]{2}{*}{$\lg G$} & $<20(n=1318)$ & 154 & 17333 & 8.9 & 1.0 (Ref. group) & \\
\hline & $20+(n=72)$ & 14 & 973 & 14.4 & $1.6(0.9,2.8)$ & 0.097 \\
\hline \multirow[t]{2}{*}{$\operatorname{lgM}$} & $<20(n=1320)$ & 156 & 17411 & 9.0 & 1.0 (Ref. group) & \\
\hline & $20+(n=70)$ & 12 & 894 & 13.4 & $1.5(0.8,2.6)$ & 0.22 \\
\hline \multirow[t]{2}{*}{$\lg \mathrm{A}$} & $<20(n=1379)$ & 164 & 18119 & 9.1 & 1.0 (Ref. group) & \\
\hline & $20+(n=11)$ & 4 & 187 & 21.4 & $2.4(0.9,6.4)$ & 0.088 \\
\hline \multirow[t]{2}{*}{ RVVT } & $>45(n=1208)$ & 126 & 15924 & 7.9 & 1.0 (Ref. group) & \\
\hline & $45+(n=78)$ & 12 & 1096 & 11.0 & $1.3(0.7,2.4)$ & 0.33 \\
\hline
\end{tabular}

Table 4 Relationship between venous thrombotic event and mean levels of anticardiolipin isotypes

\begin{tabular}{|c|c|c|c|c|c|c|}
\hline $\begin{array}{l}\mathrm{aCL} \\
\text { measure }\end{array}$ & $\begin{array}{l}\text { Subgroup defined by geometric } \\
\text { mean titre over all measures } \\
\text { during cohort }\end{array}$ & $\begin{array}{l}\text { No. of } \\
\text { thromboses }\end{array}$ & $\begin{array}{l}\text { No. of } \\
\text { person-years }\end{array}$ & $\begin{array}{l}\text { Rate } \\
\text { (per } \\
\text { 1000) }\end{array}$ & Rate ratios $^{*}$ & $\begin{array}{l}\mathrm{p} \\
\text { Value }\end{array}$ \\
\hline \multirow[t]{2}{*}{$\lg G$} & $<20$ & 152 & 17259 & 9.2 & 1.0 (Ref group) & \\
\hline & $20+$ & 16 & 935 & 17.1 & $1.9(1.1,3.2)$ & 0.015 \\
\hline \multirow[t]{2}{*}{$\lg M$} & $<20$ & 157 & 17315 & 9.1 & 1.0 (Ref group) & \\
\hline & $20+$ & 11 & 879 & 12.5 & $1.3(0.7,2.4)$ & 0.36 \\
\hline \multirow[t]{2}{*}{$\lg A$} & $<20$ & 165 & 17995 & 9.2 & 1.0 (Ref group) & \\
\hline & $20+$ & 3 & 199 & 15.1 & $1.7(0.5,5.3)$ & 0.37 \\
\hline \multirow[t]{2}{*}{ RVVT } & $<45$ & 100 & 16173 & 6.2 & 1.0 (Ref. group) & \\
\hline & $45+$ & 13 & 1071 & 12.1 & $1.9(1.1,3.4)$ & 0.028 \\
\hline
\end{tabular}

aCL, anticardiolipin antibody; RVVT, Russell's viper venom time. 
Table 5 Relationship between combinations of anticardiolipin isotypes and lifetime rates of thrombotic events

\begin{tabular}{|c|c|c|c|c|c|c|}
\hline $\begin{array}{l}\text { Antibody } \\
\text { combinations }\end{array}$ & Subgroup* & $\begin{array}{l}\text { No. of } \\
\text { thromboses }\end{array}$ & $\begin{array}{l}\text { No. of } \\
\text { person-years }\end{array}$ & $\begin{array}{l}\text { Rate (per } \\
\text { 1000) }\end{array}$ & Rate ratios & $\begin{array}{l}p \\
\text { Value }\end{array}$ \\
\hline \multirow[t]{4}{*}{$\begin{array}{l}\mathrm{aCL} \lg G \\
\mathrm{aCL} \lg \mathrm{M}\end{array}$} & $\begin{array}{l}\text { Neither elevated } \\
(n=1271)\end{array}$ & 248 & 15643 & 15.9 & 1.0 (Ref. group) & \\
\hline & $\begin{array}{l}\text { Elevated IgG but not } \\
\text { elevated IgM }(n=49)\end{array}$ & 19 & 576 & 33.0 & $2.0(1.3,3.3)$ & 0.0027 \\
\hline & $\begin{array}{l}\text { Elevated IgM but not } \\
\text { elevated IgG }(n=47)\end{array}$ & 11 & 533 & 20.6 & $1.3(0.7,2.3)$ & 0.47 \\
\hline & Both elevated $(n=23)$ & 6 & 274 & 21.9 & $1.3(0.6,3.0)$ & 0.49 \\
\hline \multirow[t]{4}{*}{$\begin{array}{l}\text { aCL } \lg G \\
\text { aCL } \lg A\end{array}$} & $\begin{array}{l}\text { Neither elevated } \\
(n=1313)\end{array}$ & 257 & 16109 & 16.0 & 1.0 (Ref. group) & \\
\hline & $\begin{array}{l}\text { Elevated IgG but not } \\
\text { elevated IgA }(n=66)\end{array}$ & 22 & 739 & 30.0 & $1.8(1.2,2.8)$ & 0.0069 \\
\hline & $\begin{array}{l}\text { Elevated IgA but not } \\
\text { elevated IgG }(n=5)\end{array}$ & 2 & 66 & 30.3 & $2.0(0.5,8.0)$ & 0.33 \\
\hline & Both elevated $(n=6)$ & 3 & 111 & 27.0 & $1.7(0.5,5.2)$ & 0.38 \\
\hline \multirow[t]{4}{*}{$\begin{array}{l}\text { aCL } \lg M \\
\text { aCL IgA }\end{array}$} & $\begin{array}{l}\text { Neither elevated } \\
(n=1313)\end{array}$ & 263 & 16129 & 16.3 & 1.0 (Ref. group) & \\
\hline & $\begin{array}{l}\text { Elevated IgM but not } \\
\text { elevated IgA }(n=66)\end{array}$ & 16 & 719 & 22.2 & $1.3(0.8,2.2)$ & 0.29 \\
\hline & $\begin{array}{l}\text { Elevated IgA but not } \\
\text { elevated IgM }(n=7)\end{array}$ & 4 & 90 & 44.6 & $2.9(1.1,7.7)$ & 0.037 \\
\hline & Both elevated $(n=4)$ & 1 & 88 & 11.4 & $0.7(0.1,4.8)$ & 0.70 \\
\hline
\end{tabular}

Table 5 shows the relationship between combinations of different anticardiolipin isotypes and thromboses. Those with elevations in two different anticardiolipin isotypes did not appear to be at higher risk than those with a single isotype elevation.

Table 6 shows the relationship between combinations of anticardiolipin isotype $\mathrm{IgG}$ with the presence of lupus anticoagulant. Those with both elevated IgG and RVVT did not appear to be at higher risk than those with elevated IgG or RVVT alone.

\section{DISCUSSION}

The risk of thrombosis associated with antiphospholipid antibodies has been studied most thoroughly in populations with SLE, of whom 12\%-30\% have anticardiolipin antibodies and $15 \%-34 \%$ have lupus anticoagulant. ${ }^{7}$ In patients with SLE having antiphospholipid antibodies, $38 \%$ have both anticardiolipin and lupus anticoagulant. ${ }^{7}$ In general, about $50 \%$ of patients with SLE who have antiphospholipid antibodies have a history of either venous or arterial thrombosis. ${ }^{7}$ Overall, it is widely accepted that lupus anticoagulant has the strongest correlation with thrombosis and adverse pregnancy outcomes. ${ }^{6}{ }^{8-15}$ Traditional cardiovascular risk factors such as hypertension, obesity, hyperlipidaemia, homocysteinaemia and smoking have been found to contribute to arterial events, as well. ${ }^{16-18}$

The thrombotic risk of anticardiolipin antibodies, particularly high-titre IgG anticardiolipin, has been known for some time..$^{2-419}{ }^{20}$ However, recently, the importance of anticardiolipin has been challenged in obstetric APS

Table 6 Joint relationship between combinations of elevated $\operatorname{lgG} \mathrm{aCL}$ and elevated RVVT and risk of thrombosis

\begin{tabular}{llllllr}
\hline $\begin{array}{l}\text { Antibody } \\
\text { combinations }\end{array}$ & Subgroup* & $\begin{array}{l}\text { No. of } \\
\text { thromboses }\end{array}$ & $\begin{array}{l}\text { No. of } \\
\text { person-years }\end{array}$ & $\begin{array}{l}\text { Rate (per } \\
1000)\end{array}$ & Rate ratios & p Value \\
\hline $\begin{array}{l}\text { aCL IgG } \\
\text { RVVT }\end{array}$ & $\begin{array}{l}\text { Neither elevated } \\
(n=1246)\end{array}$ & 228 & 15351 & 14.9 & 1.0 (Ref. group) & \\
$\begin{array}{l}\text { Elevated IgG but not } \\
\text { elevated RVVT }(n=41)\end{array}$ & 17 & 474 & 35.9 & $2.4(1.4,3.9)$ & 0.0006 \\
$\begin{array}{l}\text { Elevated RVVT but not } \\
\text { elevated IgG ( } n=72)\end{array}$ & 31 & 825 & 37.6 & $2.4(1.7,3.6)$ & $<0.0001$ \\
$\begin{array}{l}\text { Both } \\
\text { elevated }(n=31)\end{array}$ & 8 & 376 & 21.3 & $1.4(0.7,2.8)$ & 0.36 \\
\hline
\end{tabular}

*'Elevated' IgG means a geometric mean titre of $\geq 20$. 'Elevated' RVVT means an RVVT of $\geq 45$.

RVVT, dilute Russell's viper venom time. 
by the Promisse study, which found that only the lupus anticoagulant predicted adverse pregnancy outcomes. ${ }^{8}$ The unresolved issue is with regard to the thrombogenicity of the other isotypes and whether adding isotypes improves the predictive value. The IgG anticardiolipin isotype has been shown to be an independent risk factor for thrombosis in several studies, but IgA anticardiolipin has been recognised as a risk factor only recently. ${ }^{2}{ }^{21}$ The IgM anticardiolipin isotype has only been weakly (if at all) associated with thrombosis. ${ }^{21-23}$

The IgA anticardiolipin isotype was not included as part of the revised APS criteria. ${ }^{1}$ Although the IgA anticardiolipin isotype is rare as an isolated finding (usually it is combined with either IgG or IgM anticardiolipin), it may be an independent risk factor for thrombosis. ${ }^{2}$ In a mouse model, administration of IgA anticardiolipin led to an increased rate of thrombosis. ${ }^{24}$ Mehrani and Petri $^{21}$ found a significant association of IgA anticardiolipin and venous thrombosis in human SLE (OR: 5.26). We found that elevated geometric mean IgA anticardiolipin was associated with higher rates of thrombosis (but elevated IgA is less common than elevated IgG or IgM).

Although included as part of the Sydney APS classification criteria, there is controversy on the clinical importance of IgM anticardiolipin. Either a small association with thrombosis or none at all has been found with the IgM isotype. Samarkos $e t a l^{25}$ found an association of IgM anticardiolipin with venous thrombosis $(\mathrm{p}=0.001)$, but could not show any association with arterial thrombosis. ${ }^{2}$ Danowski $e t a l^{22}$ showed no increase in either venous or arterial thrombosis in patients with $\operatorname{IgM}$ anticardiolipin positivity.

Recently, in an attempt to combine antiphospholipid antibodies to improve risk assessment, Otomo $e t a l^{26}$ analysed the predictive value of the antiphospholipid score in a retrospective study of mixed autoimmune cohort with approximately $40 \%$ of patients having SLE. It consisted of a score given for each antibody (lupus anticoagulant, anticardiolipin, anti- $\beta 2$-glycoprotein 1 and anti-phosphatidylserine/prothrombin complex) depending on the isotype, titre and assay used. For anticardiolipin, the scores were 20 for IgG high titre (>30 GPL), 4 for low/moderate titres (>18.5 GPL) and 2 for IgM (>7 MPL). Patients with higher antiphospholipid scores had a stronger risk of thrombosis compared with patients with lower scores. Similarly, Sciascia et $a t^{27}$ created the Global APS score which differs in attributing 'points' to antiphospholipid antibodies and adding traditional cardiovascular risk factors for thrombosis, such as hypertension, hyperlipidaemia, smoking and oestrogen exposure. This study was cross-sectional in a large cohort of patients with SLE.

Our results confirm that anticardiolipin IgG is associated with a greater risk of thrombosis. In our cohort, those with higher geometric mean IgM anticardiolipin were not at a substantial or significant increased risk of thrombosis. Those with higher geometric mean IgA anticardiolipin were found to be at higher risk, but this condition was rare and the higher risk was not statistically significant. There was no evidence that having two isotypes resulted in a higher risk than having just one or that having anticardiolipin on top of lupus anticoagulant increased the risk.

The strengths of our study included the large number of patients with SLE, large number of thrombotic events, multiple measurements of anticardiolipin and lupus anticoagulant for each patient and the prospective assessment of most of the thrombotic events. A limitation is that, for some patients, the thromboses were not observed prospectively. A second limitation is that our exposure variables (anticardiolipin and RVVT) were measured during cohort participation, whereas our outcome variable (thrombotic event) was measured at any time after SLE diagnosis (and could have preceded cohort participation). Thus, the interpretability of our findings depends on the assumption that the anticardiolipin levels measured during cohort participation represent the approximate anticardiolipin levels that a patient experienced since SLE diagnosis. We think this is a reasonable assumption, as the occurrence of a thrombosis and the resulting treatment (warfarin) are unlikely to affect anticardiolipin measures made at a later date.

\section{CONCLUSION}

The association of anticardiolipin with thrombosis depends on whether the event is venous thrombosis or arterial thrombosis (which is important predictive information for clinicians). Anticardiolipin IgG, but not IgM geometric mean, is associated with greater risk. Lupus anticoagulant remains the single best predictor of thrombosis. Surprisingly, adding different anticardiolipin isotypes seems to decrease the isolated IgG anticardiolipin risk for thrombosis. Thus, additive scores do not appear to be valid in SLE. We are not implicitly recommending that the geometric mean titres should be used in clinical practice. We do recognise that APS Classification Criteria recommend looking at repeat titres. Our findings shed light on the relationship between anticardiolipin and risk of thrombosis.

Contributors The authors believe that the above article gives more body of evidence supporting the lack of increase thrombosis risk attributed to IgM anticardiolipin. Also, it shows very clearly that adding anticardiolipin antibody isotypes does not increase thrombosis risk; therefore, score system for APS may not be applicable for patients with SLE.

Funding The Hopkins Lupus Cohort is supported by NIH AR43727.

Competing interests None declared.

Ethics approval Johns Hopkins University School of Medicine.

Provenance and peer review Not commissioned; externally peer reviewed.

Data sharing statement All relevant data for this study are being published.

Open Access This is an Open Access article distributed in accordance with the Creative Commons Attribution Non Commercial (CC BY-NC 4.0) license, which permits others to distribute, remix, adapt, build upon this work noncommercially, and license their derivative works on different terms, provided the original work is properly cited and the use is non-commercial. See: http:// creativecommons.org/licenses/by-nc/4.0/ 


\section{REFERENCES}

1. Miyakis S, Lockshin MD, Atsumi T, et al. International consensus statement on an update of the classification criteria for definite antiphospholipid syndrome (APS). J Thromb Haemostasis 2006;4:295-306.

2. Shen YM, Lee R, Frenkel E, et al. IgA antiphospholipid antibodies are an independent risk factor for thromboses. Lupus 2008;17:996-1003

3. Sallai KK, Nagy E, Bodó I, et al. Thrombosis risk in systemic lupus erythematosus: the role of thrombophilic risk factors. Scand $J$ Rheumatol 2007;36:198-205.

4. Somers E, Magder L, Petri M. Antiphospholipid antibodies and incidence of venous thrombosis in a cohort of patients with systemic lupus erythematosus. J Rheumatol 2002;29:2531-6.

5. Abu-Shakra M, Gladman DD, Urowitz MB, et al. Anticardiolipin antibodies in systemic lupus erythematosus: clinical and laboratory correlations. Am J Med 1995;99:624-8.

6. Petri M, Rheinschmidt M, Whiting-O'Keefe $Q$, et al. The frequency of lupus anticoagulant in systemic lupus erythematosus: a study of 60 consecutive patients by activated partial thromboplastin time, Russell viper venom time, and anticardiolipin antibody. Ann Intern Med 1987;106:524-31.

7. Hanly JG. Antiphospholipid syndrome: an overview. CMAJ 2003;168:1675-82.

8. Lockshin MD, Kim M, Laskin CA, et al. Prediction of adverse pregnancy outcome by the presence of lupus anticoagulant, but not anticardiolipin antibody, in patients with antiphospholipid antibodies. Arthritis Rheum 2012;64:2311-18.

9. Tarr T, Lakos G, Bhattoa HP, et al. Analysis of risk factors for the development of thrombotic complications in antiphospholipid antibody positive lupus patients. Lupus 2007;16:39-45.

10. Petri M, Orbai AM, Alarcón GS, et al. Derivation and validation of the Systemic Lupus International Collaborating Clinics classification criteria for systemic lupus erythematosus. Arthritis Rheum 2012;64:2677-86.

11. Wahl DG, Guillemin F, de Maistre E, et al. Risk for venous thrombosis related to antiphospholipid antibodies in systemic lupus erythematosus-a meta-analysis. Lupus 1997;6:467-73.

12. Derksen R, Hasselaar $P$, Blokzijl L, et al. Coagulation screen is more specific than the anticardiolipin antibody ELISA in defining a thrombotic subset of lupus patients. Ann Rheum Dis 1988;47: 364-71.

13. Somers E, Magder L, Petri M. Antiphospholipid Antibodies and incidence of venous thrombosis in a cohort of patient with Systemic Lupus Erythematosus. J Rheumatol 2002;29:2531-6.

14. Galli M, Luciani D, Bertolini G, et al. Anti-beta 2-glycoprotein I, antiprothrombin antibodies, and the risk of thrombosis in the antiphospholipid syndrome. Blood 2003;101:1827-32.
15. Urbanus RT, Siegerink B, Roest M, et al. Antiphospholipid antibodies and risk of myocardial infarction and ischaemic stroke in young women in the RATIO study: a case-control study. Lancet Neurol 2009;8:998-1005.

16. Petri M, Roubenoff R, Dallal GE, et al. Plasma homocysteine as a risk factor for atherothrombotic events in systemic lupus erythematosus. Lancet 1996;348:1120-4.

17. Petri M, Perez-Gutthann S, Spence D, et al. Risk factors for coronary artery disease in patients with systemic lupus erythematosus. Am J Med 1992;93:513-19.

18. Magder LS, Petri M. Incidence of and risk factors for adverse cardiovascular events among patients with systemic lupus erythematosus. Am J Epidemiol 2012;176:708-19.

19. Long AA, Ginsberg JS, Brill-Edwards $P$, et al. The relationship of antiphospholipid antibodies to thromboembolic disease in systemic lupus erythematosus: a cross- sectional study. Thromb Haemost 1991;66:520-4.

20. Ginsberg JS, Brill-Edwards P, Johnston M, et al. Relationship of antiphospholipid antibodies to pregnancy loss in patients with systemic lupus erythematosus: a cross sectional study. Blood 1992;80:975-80.

21. Mehrani T, Petri M. IgM anti- $\beta 2$ glycoprotein I is protective against lupus nephritis and renal damage in systemic lupus erythematosus. J Rheumatol 2011;38:450-3.

22. Danowski A, de Azevedo MN, de Souza Papi JA, et al. Determinants of risk for venous and arterial thrombosis in primary antiphospholipid syndrome and in antiphospholipid syndrome with systemic lupus erythematosus. J Rheumatol 2009;36:1195-9.

23. Vikerfors A, Johansson AB, Gustafsson JT, et al. Clinical manifestations and anti-phospholipid antibodies in 712 patients with systemic lupus erythematosus: evaluation of two diagnostic assays. Rheumatology (Oxford) 2013;52:501-9.

24. Pierangeli SS, Liu XW, Barker JH, et al. Induction of thrombosis in a mouse model by $\operatorname{lgG}$, IgM and IgA immunoglobulins from patients with the antiphospholipid syndrome. Thromb Haemost 1995;74:1361-7.

25. Samarkos M, Davies KA, Gordon C, et al. Clinical significance of $\lg \mathrm{A}$ anticardiolipin and anti-beta2-GP1 antibodies in patients with systemic lupus erythematosus and primary antiphospholipid syndrome. Clin Rheumatol 2006;25:199-204.

26. Otomo K, Atsumi T, Amengual O, et al. Efficacy of the antiphospholipid score for the diagnosis of antiphospholipid syndrome and its predictive value for thrombotic events. Arthritis Rheum 2012:64:504-12.

27. Sciascia S, Sanna G, Murru V, et al. GAPSS: the Global Anti-Phospholipid Syndrome Score. Rheumatology (Oxford) 2013;52:1397-403. 